\title{
Prospects of legal regulation and use of the digital rouble
}

\author{
Ekaterina Kostikova ${ }^{1, *}$, Diana Alekseeva ${ }^{2}$, Svetlana Rybakova ${ }^{3}$, and Anna Savina ${ }^{4}$ \\ ${ }^{1}$ Russian State University of Justice, 69 Novocheremushinskaya St., Moscow, Russia, keg2003@bk.ru \\ ${ }^{2}$ Financial University under the Government of the Russian Federation, 49 Leningradsky Prospekt, Moscow, Russia, Kutafin \\ Moscow State Law University (MSAL), 9 Sadovaya-Kudrinskaya St., Moscow, Russia, alekseeva.dg@yandex.ru \\ ${ }^{3}$ Saratov State Law Academy, 1 Volskaya street, Saratov, Russia, svrybakova@mail.ru \\ ${ }^{4}$ Derzhavin Tambov State University, 33 Internatsionalnaya St., Tambov, Russia, anna.savina56@mail.ru
}

\begin{abstract}
This article considers the problems associated with the prospects of central banks issuing and circulating digital currency, in particular the digital rouble. The study found that at present there is virtually no need to issue such a currency as an alternative to cryptocurrency (virtual currency), because cryptocurrency has largely lost its properties as a means of payment with the acquisition of the qualities of an investment instrument. The advantages of a cryptocurrency over non-cash money, which is familiar and also has excellent qualities as a settlement tool, are also not obvious. The positioning of offline payments as a benefit of the digital rouble is questionable given the prospects of full Internet coverage in Russia and the significant technological and legal complexities involved in the organization and control of such payments. Building trust in the new form of the national currency, without which it will not be in demand, will require building a mechanism for legal protection of consumers' rights. There is also a need for a mechanism to address the risks associated with laundering proceeds of crime, financing terrorism and proliferation of weapons of mass destruction. It is difficult to formalise such a mechanism in the absence of international legal regulation
\end{abstract}

\section{Introduction}

Since 2018, several states have been developing and implementing projects to introduce central bank digital currency (CBDC) into money circulation.

In November 2018, the Riksbank of Sweden announced Europe's first trial of a sovereign digital currency, the e-Crown, which, according to Stefan Ingves, Governor of the Riksbank, is a pilot version of the Riksbank's new type of money [1]. In October 2020, China began testing China's national digital currency, DCEP (Digital Currency Electronic Payment). The project has been piloted in Shenzhen, Suzhou and Chengdu, as well as in the Xiongnan New Area. The digital yuan will be used to pay for transport fares and food. Testing of the DCEP is scheduled to continue at the 2022 Winter Olympics. The Bank of England also announced preparations for a digital currency in March 2020. It indicated that the digital currency, as an electronic form of money by the central bank, would be intended for payments by households and businesses and would not be a crypto-asset or cryptocurrency [2].

In October 2020, the Central Bank of the Russian Federation published a report on "The Digital Rouble" (report) (Central Bank of the Russian Federation [3]. The report invited the public to discuss the prospects of issuing the digital rouble as a new form of national Russian currency. The Russian central bank is positioning the digital rouble as a central bank digital currency (CBDC) that combines features of cash and non-cash forms of money: a unique digital code similar to the series and number on Bank of Russia banknotes and no physical carrier like non-cash money, allowing for remote payments. The digital rouble would also have other characteristics of a national currency: a monopoly state issuing centre and the status of legal tender. However, the digital rouble is not intended to replace cash and non-cash: it is seen as a third form of money.

\section{Problem Statement}

Initiatives to issue digital currency by national central banks emerged as a response to the creation and largescale diffusion of a radical innovation generated by new Internet technologies [4] - cryptocurrency [5] (virtual currency). The first and most popular of such currencies is Bitcoin.

The monetary launch of central bank digital currencies is an offer to interested consumers from an official issuer of an analogue of "digital coins" released by decentralised issuance systems.

However, there are doubts about the feasibility of introducing a new form of money. This is evident from central bank projects to launch such a currency in Europe and China in test mode, as well as from a public

\footnotetext{
*Corresponding author: keg2003@bk.ru
} 
discussion initiated in Russia. The Russian issuer has no understanding of the benefits of the digital rouble. There is no clear understanding of the legal issues associated with its issuance and circulation. It is impossible to shape the digital currency model of the Bank of Russia without it.

\section{Research Questions}

The raised issue requires research into the following questions:

1. The need to introduce central bank digital currency as a consumer-demanded alternative to cryptocurrency.

2. The advantages of the digital rouble compared to non-cash money

3. The legal problems related to the issuance and circulation of the digital rouble.

\section{Purpose of the Study}

Purposes of this study include:

- To determine the feasibility of introducing central bank digital currency, including the digital rouble, as a consumer-demanded alternative to cryptocurrency.

- To identify the advantages of the digital rouble compared to non-cash money.

- To identify the legal problems associated with the issuance and circulation of the digital rouble.

\section{Research Methods}

The authors used the following research methods: system analysis, formal-legal, and generalization.

\section{Findings}

\subsection{Central bank digital currencies as an alternative to cryptocurrency}

Cryptocurrency is a modern economic phenomenon. Researchers identified characteristics to consider cryptocurrency as a parallel to the national currency [6], an alternative form of liquidity to traditional monetary assets [7]. The European Central Bank in its February 2015 report "Virtual Currency Schemes - Further Analysis", in describing cryptocurrency, noted that in some circumstances it is feasible to use it as an alternative to money (European Central Bank [ECB], 2015) [8]. In October 2015, the Bank for International Settlements pointed out the monetary characteristics of cryptocurrencies in its Digital Currencies report [9]. At the same time, there was also a debate about the extent to which cryptocurrencies have inherent money functions [10]. Cryptocurrency is fundamentally different from national (fiat) money: it is not issued and guaranteed by any state [11], central bank, credit institution or electronic money institution [8]; its price process is not regulated or stabilised by third parties such as the central bank [12].
The cryptocurrency's meteoric success was due to its consumer properties as a means of payment. It is primarily about Bitcoin, whose market capitalisation of cryptocurrencies at the beginning of 2020 is over USD 194 billion, of which Bitcoin accounts for USD 124 billion [13]. Researchers noted the following advantages of the cryptocurrency compared to national (fiat) money: low inflation rate due to limited issuance (Bitcoin 21 million) [14]; transaction security ensured by special technologies [15]; accessibility of cross-border transactions [16] due to lack of connection to national borders [17]; anonymity [18].

However, the Bitcoin launch was based on idealistic ideas about the possibility of replacing existing monetary systems with an alternative system [18]. Today, cryptocurrency acquired, in addition to its properties as a means of payment (settlement), the properties of an investment instrument. The high volatility in the value of cryptocurrencies means that their inherent properties as a payment (settlement) instrument are replaced by those of an investment asset. This significantly reduces the competitiveness of cryptocurrencies regarding national currencies, whose payment properties are secured by currency regulation in the issuing countries.

Russian legislation reflected the dual nature of cryptocurrencies. The Federal Law of 31.07. 2020 No. 259-FZ "On Digital Financial Assets, Digital Currency and on Amendments to Certain Legislative Acts of the Russian Federation", calling cryptocurrency a digital currency, defined that it is a set of electronic data contained in an information system that is offered and may be accepted as (1) a means of payment that is not a monetary unit of the Russian Federation, a foreign state or an international monetary or settlement unit, and (2) as an investment; there is no obliged person to the holders of electronic data.

In addition, the payment properties of decentralized digital currencies are suppressed by prohibitions and restrictions on their use, including in payments.

In particular, in Russia, the above-mentioned federal law prohibits payments for goods, works and services in digital currency, as well as the dissemination of information on the possibility of such payments. This prohibition applies to persons who can be conditionally called Russian residents: legal entities, separate subdivisions of international and foreign organizations established in the territory of Russia, natural persons permanently residing in the Russian Federation (for at least 183 days during the next 12 consecutive months). This prohibition is reinforced by rules relating to the possession of the currency by Russian residents: judicial protection of the rights of such entities associated with the possession of the digital currency will only be possible if they inform the state of the facts of their possession, transactions and operations with the digital currency.

Thus, at the present stage, cryptocurrency is unable to compete with national currencies, including digital currencies, so the introduction of central bank digital currencies as an alternative to cryptocurrency is not appropriate. However, it is reasonable to give central bank digital currencies the properties of virtual money, 
which were incorporated when creating cryptocurrency and provided consumers with interest in it.

\subsection{On the advantages of the digital rouble compared to non-cash money}

Modern non-cash has excellent consumer properties (affordability of mobile payments, speed, low transaction costs). In this light, the desirability of central bank digital currencies should stem from their unique qualities.

The exceptional advantage of the digital rouble is the possibility to use it in offline mode, where consumers will be able to make payment transactions without access to the Internet. This new currency option is relevant for remote areas not covered by the Internet. However, the Bank of Russia expresses doubts about its future relevance, as over time the Internet will cover the entire country and users everywhere will be able to make the usual cashless transfers without hindrance. The Bank of Russia is planning to conduct a special study for forming an opinion on the feasibility of giving the digital rouble such a feature. A balanced approach is necessary because developing technology for offline payments (including storing digital currency on devices that support wireless services; synchronization with an online wallet) will incur significant costs. In addition, such settlements carry risks associated with the loss of the device on which they are stored (actually a wallet), violations of the requirements of Federal Law of 07.08.2001 No. 115-FZ "On Counteracting the Legalization (Laundering) of Proceeds of Crime and the Financing of Terrorism".

Another advantage of the digital rouble could be the availability of cross-border transfers, including reducing the transaction costs of such transactions. This quality is highly appreciated in cryptocurrency settlements; it was ensured by the absence of restrictions imposed by individual jurisdictions on such transfers. The accessibility of cross-border transfers in digital roubles can result not from overcoming jurisdictional restrictions, but from reducing the number of intermediaries in such transactions. This will require adopting and legislating a digital currency model with a minimum number of participants (intermediaries). The Bank of Russia will also need to ensure interaction with foreign payment systems, which is necessary for the conversion of the digital rouble.

A unique useful feature of the digital rouble compared to non-cash money is the ability to accurately identify participants in settlement transactions. However, transaction identification has risks associated with data protection issues, compliance with legislation on antimoney laundering, financing terrorism and proliferation of weapons of mass destruction.

Thus, at present, the advantages of the digital rouble over non-cash money are not obvious. And without such benefits, the Bank of Russia's digital currency may not be in demand, as the choice of money form for the consumer is voluntary (given the limitations of cash payments between economic entities) and cashless payments have become customary for the widest range of individuals. Therefore, the Bank of Russia needs to define more clearly the useful qualities of the new form of the national currency that should serve as a basis for the digital rouble model and the legal framework for its operation.

\subsection{Separate legal issues related to the issuance and circulation of the digital rouble}

Only high quality legal regulation serves as a criterion for public confidence in the financial and monetary system [19], including the digital rouble. Thus, it is important to identify the legal problems related to the issuance and circulation of the digital rouble.

Monetary circulation, including central banks' digital currencies, involves risks associated with laundering proceeds of crime, financing terrorism and proliferation of weapons of mass destruction.

The introduction of the digital rouble raises the question of establishing a mechanism to counter such threats, especially in terms of controlling monetary transactions.

In the current system, control functions are shared between the Bank of Russia and credit institutions, as well as other entities involved in cash transactions. The central bank believes that it would be efficient to retain the current functionality of these entities with regard to digital rouble transactions as well, upgrading it as necessary.

However, such an approach is fraught with legal complexities.

The Financial Action Task Force currently distinguishes between the virtual currency (cryptocurrency) and electronic money to assess and manage anti-money laundering, financing terrorism and proliferation of weapons of mass destruction [19]. There is no FATF-formulated regulation for central bank digital currencies, which will cause difficulties in reforming national legislation.

In particular, problems will arise in the development of the following documents:

- rules for opening and maintaining individual ewallets for storing digital roubles in terms of identifying customers, customer representatives, beneficiaries and beneficial owners, storing and periodically updating information about these entities, and determining the grounds for refusing to open an e-wallet;

- internal control rules in terms of anti-money laundering, financing terrorism and proliferation of weapons of mass destruction related to digital currency transactions. In the current context of legal uncertainty regarding existing legal categories ("unusual", "suspicious", "questionable" and "transit" transactions), confusing grounds for mandatory and optional controls in this area, gaps and conflicts in relevant legislation, this task seems ineffective [20].

Another issue that is important to address is providing a consumer protection mechanism for the 
digital rouble. The financial literacy of the Russian population remains rather low, even with regard to financial products that have long been known and widely marketed. The emergence of digital rouble as a new financial product will inevitably entail the emergence of unfair practices (mis-selling) both in opening and maintaining individual e-wallets and in transactions and transactions with them. Therefore, it is necessary to develop and enshrine in law protective mechanisms. This is necessary to build public confidence in the digital rouble.

It is important to exclude the application of liability measures in transactions and operations involving the digital rouble to bona fide actors. This requires a clear formulation of the grounds for such measures, including clarification of the offences, since inaccurate and incorrect wording of the objective side of the offence often leads to unlawful prosecution even today [21]. The risks of criminal prosecution of innocent people will increase with the introduction of digital currency.

\section{Conclusion}

The authors conclude that doubts by the Bank of Russia about the feasibility of introducing the digital rouble into monetary circulation are reasonable: there is no need to offer consumers a governmental alternative to cryptocurrency; the advantages of central bank digital currency over non-cash money are not obvious; solving the legal problems associated with the issue and circulation of the digital rouble is difficult at the moment.

In such circumstances, the Bank of Russia needs to clearly define the public interests that will form the basis for the digital rouble model and the legal basis for the issuing and circulation of the national currency in the new form [23].

\section{References}

1. S. Ingves, The e-krona and the payments of the future (2018),

URL: https://www.riksbank.se/globalassets/media/tal/enge lska/ingves/2018/the-e-krona-and-the-payments-ofthe-future.pdf (date of access: 16.03.20).

2. Bank of England (2020), URL: https://www.bankofengland.co.uk/-

/media/boe/files/paper/2020/central-bank-digitalcurrency-opportunities-challenges-anddesign.pdf?la=en\&hash=DFAD18646A77C00772A F1C5B18E63E71F68E4593 (date of access: 16.03.20).

3. Bank of Russia (2020), URL: https://cbr.ru/analytics/d_ok/dig_ruble/ (date of access: 16.03.20).

4. E. Iidogan, Blockchain-based cryptocurrency equilibrium model (2018), URL: https://doi.org/10.2139/ssrn.3152803(date of access: 16.03.20).
5. S. Corbett \& B. Lucy \& A. Urquhart \& L. Yarovaya, International Review of Finance 62, 182 - 199 (2019).

6. L. Larue, Ecological Economics (2020), URL: https://doi.org/10.1016/j.ecolecon.2020.106823(date of access: 16.03.20).

7. R. Boehme, \& N. Christine, \& B. Edelman, \& T. Moore Perspective 29 (2), 213 - 238 (2015)

8. European Central Bank (2015). Virtual currency schemes - a further analysis. URL: https:/www.ecb.europa.eu/pub/pdf/other/virtualcurr encyschemesen.pdf?d5b48352d3ce982d8c4507dcad 038018 (date of access: 16.03.20).

9. Bank for International Settlements (2015). Digital currencies. URL: https://www.bis.org/cpmi/publ/d137.pdf (date of access: 16.03.20).

10. D. Ermak, Academic Press 2, 31 - 43 (2015)

11. Bank of Russia (2017), URL: http://cbr.ru/content/document/file/36009/rev_ico.pd $\underline{f}$ (date of access: 16.03.20).

12. L. Schilling, \& H. Uhlig, Journal of Monetary Economics, 16-26. (2019), URL: https://doi.org/10.1016/j.jmoneco.2019.07.002 (date of access: 16.03.20).

13. Y. Ma, F. Ahmad, \& M. Liu, \& Z. Wang, Technological Forecasting and Social Change. (2020), URL: https://doi.org/10.1016/j.techfore.2020.120265 (date of access: 16.03.20).

14. J. Papp, J. Pittsburgh, Technol. Legal Policy, 33-56 (2014)

15. S. Bayern, Wash. Lee Law Rev, 22-34 (2014)

16. V. Maese, The Banking Law Journal 133 (8), 468 (2016).

17. V.A. Mez, \& A.V. Avery, \& B.A. Naftalis, \& S.P. Vink, \& Yu.D. Valdez, The Banking Law Journal, 133 (8), 468-471 (2016)

18. E. Sayedi, \& A Brostrem, \& F. Ruiz, Economy of small buses (2020), URL: https://doi.org/10.1007/s11187-019-00309-8 (date of access: 16.03.20).

19. M.K. Borodavina, \& S.V. Rybakova, \& A.V. Savina, \& A.P. Khakhulina, Enforcement, 4, (1), 75-84 (2020)

20. Financial Action Task Force (2014). Virtual Currencies - Key Definitions and Potential AML/CFT Risks. URL: http://www.fedsfm.ru/content/files/documents/fatf/v irtualnye_valyuty_fatf_2014.pdf(date of access: 16.03.20).

21. D.G. Alekseeva, Banking law 4, 9-17 (2018)

22. D.G. Alekseeva, \& I.E. Mikheeva, \& T.P. Suspitsyna, All-Russian criminological journal 13 (6), 962-970 (2019)

23. I.A. Tsindeliani, I.V. Bit-Shabo, A.D. Selyukov, M.M. Proshunin, E.G. Kostikova, S.S. Tropskaya, S.V. Rybakova, Journal of Legal, Ethical and Regulatory Issues 22 (5), 1-12 (2019) 